\title{
ICAM-1 and integrin expression on isolated human alveolar type II pneumocytes
}

\author{
J. Guzman*, T. Izumi**, S. Nagai**, U. Costabel ${ }^{\dagger}$
}

\begin{abstract}
ICAM-1 and integrin expression on isolated human alveolar type II pneumocytes. J. Guzman, T. Izumi, S. Nagai, U. Costabel. OERS Journals Ltd.

ABSTRACT: Adhesion molecules are involved in the recruitment of leucocytes to sites of inflammation. In this study, we determined the expression of several adhesion molecules on isolated human alveolar type II pneumocytes.

Type II pneumocytes were isolated from 10 normal lung specimens, by enzymatic digestion with dispase, followed by metrizamide gradient centrifugation and panning on immunoglobulin G (IgG)-coated plastic dishes. With the freshly isolated type II cells, immunostaining was performed using a sensitive immunoperoxidase slide technique.

In all cases, 60-90\% of type II cells were positive for intercellular adhesion molecule-1 (ICAM-1) (CD54). A minor portion of type II cells expressed the alpha 4 (CD49d) subunit of the $\beta_{1}$-integrins, and the alpha-v (CD51) subunit of the vitronectin receptor. CD11a, CD11b, CD11c, CD18, CD49b, CD49e and CD49f failed to demonstrate any immunostaining with type II cells.

In conclusion, the observation of the expression of ICAM-1 and, to a lesser degree, of some integrin subunits, may indicate that alveolar type II cells participate in local immune and inflammatory responses.

Eur Respir J., 1994, 7, 736-739.
\end{abstract}

\begin{abstract}
* Allg., insb. Experimentelle Pathologie, Ruhr-Universität Bochum, Germany. ** Chest Disease Research Institute, Kyoto University, Japan. ${ }^{\dagger}$ Abt. Pneumologie und Allergologie, Ruhrlandklinik, Essen, Germany.

Correspondence: J. Guzman y Rotaeche, Allgemeine, insbesondere Experimentelle Pathologie, Gebäude MA 01-596, RuhrUniversität Bochum, Universitätstrasse 150 D-44780 Bochum, Germany.

Keywords: Human type II pneumocytes, integrins, intercellular adhesion molecule-1

Received: December 61993

Accepted after revision January 251994 Supported by Ministerium für Wissenschaft und Forschung des Landes NordrheinWestfalen Bennigsen-Foerder-Preis: Programm zur Foerderung der Forschung junger Wissenschaftlerinnen und Wissenschaftler AZ IV A6-402 30990.
\end{abstract}

Intercellular adhesion molecule-1 (ICAM-1) is an adhesion molecule of the immunoglobulin superfamily. It serves as a ligand for the leucocyte function associated antigen-1 (LFA-1) (CD11a/CD18) and Mac-1 (CD11b /CD18) integrin on human T-cells, but is also involved in adhesion of other cells. ICAM-1 can be expressed on many cells [1].

The integrins are members of a supergene family of heterodimeric receptors present on the surface of various cells [2]. They apparently function to link the extracellular environment to cytoskeletal structures. Cell-to-cell interactions and adhesion of cells to the extracellular matrix are of fundamental importance for many immunological processes in the lung. Increased adhesiveness of activated leucocytes may contribute to damage of the lung parenchyma in several pathological processes.

Recent evidence suggests that alveolar type II pneumocytes play an indirect role in immunological functions. Their major products, surfactant phospholipids and proteins, have been shown to modulate the activity of immune cells. Surfactant protein A may enhance certain macrophage activities, including phagocytosis and intracellular killing of bacteria, migration, and cytotoxicity against tumour cells. Surfactant phospholipids, on the other hand, are capable of suppressing several lymphocyte functions, including the proliferative response to mitogens, immunoglobulin production, and natural killer cell activity [3, 4]. Whether alveolar type II cells are also directly involved in immunological processes is, at present, unknown.

In the context of the new knowledge concerning the role of adhesion molecules in cell-to-cell and cellto-extracellular matrix interactions, the purpose of the present study was to investigate the expression of adhesion molecules on human alveolar type II cells isolated from normal lung tissue. We chose to use isolated type II cells for this purpose, since a recent study indicated that precise identification of the individual cell type within the alveolar septae is not possible by light microscopy with the relatively thick sections used for immunohistochemistry of frozen tissue [5].

\section{Material and methods}

\section{Isolation of alveolar type II cells}

Normal lung specimens $(30 \mathrm{~g})$ were obtained from 10 patients (6 smokers and 4 nonsmokers) undergoing lobectomy or pneumonectomy for primary lung cancer. Preoperative lung function of these subjects was normal. The area from which the lung parenchyma for cell isolation was taken was macroscopically and histologically 
free of emphysema or other pathological changes. The cell isolation was performed immediately after surgical resection. Human type II pneumocytes were isolated as described previously [6], using a combination of the procedures published by DobBs et al. [7], Edelson et al. [8], and PAPADOPOULOS et al. [9]. The isolation procedure included enzymatic digestion with dispase, and enrichment of type II cells by metrizamide gradient centrifugation, followed by panning on immunoglobulin $\mathrm{G}$ ( $\mathrm{IgG}$ )-coated plastic dishes. Immunocytochemistry was performed with the freshly isolated type II cells.

Enzymatic digestion. The lung was cut into small pieces (less than $0.5 \mathrm{~cm}^{3}$ ), which were washed thoroughly in solution I $(7.95 \mathrm{~g} \mathrm{NaCl}+0.4 \mathrm{~g} \mathrm{KCl}+1.11 \mathrm{~g} \mathrm{D}(+)$ glucose $\cdot 1 \mathrm{H}_{2} \mathrm{O}+0.46 \mathrm{~g} \mathrm{Na} \mathrm{HPO}_{4} \cdot 2 \mathrm{H}_{2} \mathrm{O}+2.38 \mathrm{~g}$ hydroxyethylpiperazine ethane sulphate acid (HEPES) and 1,000 $\mathrm{ml}$ aqua bidest) to remove excess blood; followed by incubation with $80 \mathrm{ml}$ of dispase solution $(0.2 \mathrm{~g}$ dispase in $80 \mathrm{ml}$ solution II: solution $\mathrm{I}+0.28 \mathrm{~g} \mathrm{CaCl}{ }_{2} \cdot 2 \mathrm{H}_{2} \mathrm{O}_{2}+$ $0.32 \mathrm{~g} \mathrm{MgSO}_{4} \cdot 7 \mathrm{H}_{2} \mathrm{O}_{2}, \mathrm{pH} 7.4$ ) for $45 \mathrm{~min}$ at $37^{\circ} \mathrm{C}$ with continuous stirring. After further mincing of the digested tissue, the suspension was filtered through a series of 100,50 and $20 \mu \mathrm{m}$ nylon meshes, centrifuged at $160 \times \mathrm{g}$ for $10 \mathrm{~min}$ at $4{ }^{\circ} \mathrm{C}$, and resuspended in solution II.

Metrizamide gradient centrifugation. The cells were layered on a discontinuous metrizamide gradient with the upper and lower solutions having densities of 1.040 and 1.090 , respectively. After centrifugation at $160 \times \mathrm{g}$ for $20 \mathrm{~min}$, the cells that accumulated at the interphase were removed and washed in $50 \mathrm{ml}$ solution II containing desoxyribonuclease $\left(1 \mathrm{mg} \cdot \mathrm{ml}^{-1}\right)$ to prevent cell clumping.

Panning on IgG-coated dishes. Macrophages and blood leucocytes were removed from the cell suspension by differential adherence to $100 \mathrm{~mm}$ plastic Petri dishes coated with human IgG $\left(500 \mu \mathrm{g} \cdot \mathrm{ml}^{-1}\right)$ during incubation for $60 \mathrm{~min}$ at $37^{\circ} \mathrm{C}(7,8)$. The nonadherent cells, mainly type II cells, were pooled and centrifuged at $160 \times \mathrm{g}$ for $5 \mathrm{~min}$ at $4^{\circ} \mathrm{C}$. Total cell counts were performed using a Neubauer chamber. Identification and purity of type II cells were assessed on cytocentrifuge preparations using the modified Papanicolaou stain [10].

\section{Immunocytochemistry}

The expression of ICAM-1 (ligand for $\beta_{2}$-integrins), $\beta_{1}$-integrins (extracellular matrix receptors), $\beta_{2}$-integrins (leucocyte cell adhesion molecules) and $\beta_{3}$-integrins (cytoadhesins) on type II cells was analysed using the immunoperoxidase adhesive slide assay, as described previously [11]. Briefly, $10 \mu \mathrm{l}$ of cell suspension, at a concentration of $2 \times 10^{6}$ cells $\cdot \mathrm{ml}^{-1}$ was added to each of the reaction areas of adhesive slides (Bio-Rad, Germany). After $10 \mathrm{~min}$, the cells were settled and firmly attached to the glass surface. The cells were then fixed with $0.05 \%$ glutaraldehyde solution for $5 \mathrm{~min}$. The surface marker staining was performed using a sensitive four layer peroxidase anti-peroxidase technique, followed by postfixation with $\mathrm{OsO}_{4}$. The monoclonal antibodies
Table 1. - Monoclonal antibodies used in this study

\begin{tabular}{lll}
\hline $\begin{array}{l}\text { Monoclonal } \\
\text { antibody }\end{array}$ & Source & \multicolumn{1}{c}{ Antigen } \\
\hline $\begin{array}{l}\text { IOL 54 } \\
\beta 1 \text {-integrins }\end{array}$ & Dianova & CD54 (ICAM-1) \\
IOP 49b & Dianova & CD49b (alpha-2), collagen receptor \\
IOP 49d & Dianova & CD49d (alpha-4), ligand for VCAM-1 \\
IOP 49e & Dianova & CD49e (alpha-5), fibronectin receptor \\
IOP 49f & Dianova & CD49f (alpha-6), laminin receptor \\
$\beta 2-$ integrins & & \\
IOT 16 & Dianova & CD11a (LFA-1) \\
OKM 1 & Ortho & CD11b (Mac 1) \\
Ki-M1 & Behring & CD11c (CR 4) \\
IOT 18 & Dianova & CD18 ( $\beta$-chain) \\
$\beta 3-$ integrin & & \\
IOP 51 & Dianova & CD51 (alpha-v), vitronectin receptor \\
\hline
\end{tabular}

ICAM-1: intercellular adhesion molecule-1; VCAM-1: vascular cell adhesion molecule; LFA: leucocyte function associated antigen.

(MoAbs) used in this study are listed in table 1. The percentage of positively reacting type II cells was determined for each antigen.

\section{Results}

The percentage of isolated type II cells ranged between $80-95 \%$ of total cells isolated (fig. 1). The cell viability was $95 \%$. The total number of isolated type II cells ranged between $1.5-3.0 \times 10^{7}$ cells per $30 \mathrm{~g}$ lung tissue.

In all cases, immunostaining of type II cells for ICAM1 was observed (fig. 2). Sixty to ninety percent of type II cells per case were positive. In many instances, the positive reaction for ICAM-1 was located at one side of the cell surface (fig. 3); mostly corresponding to the area closer to the nucleus. This staining pattern was in contrast to the positive reaction with an epithelial marker, HEA 125 (Progen), in which the reaction was homogeneously distributed on the cell surface.

A negative reaction of type II cells was found for CD11a, CD11b, CD11c, CD18, CD49b, CD49e, CD49f.

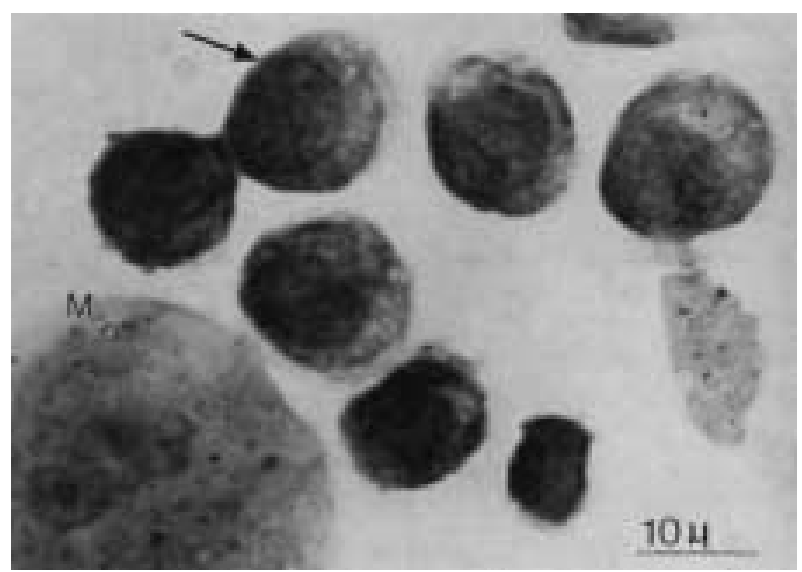

Fig. 1 - Freshly isolated human type II cells (arrow). Macrophage (M). May-Grünwald Giensa stain; original magnification $\times 100$. 


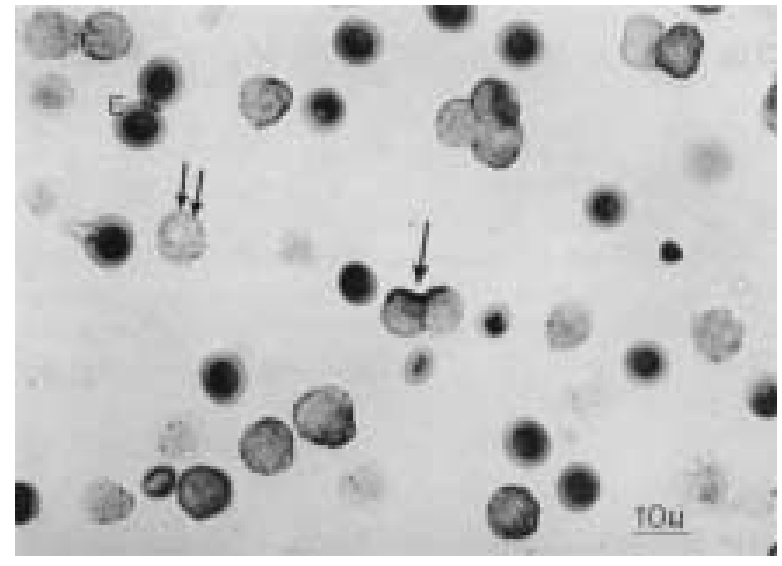

Fig. 2 - Cell surface immunostaining of isolated human type II cells for intercellular adhesion molecule-1 (ICAM-1) (CD54). Positive reacting type II cells (one arrow), negative type II cell (two arrows), erythrocytes with pseudoendogenous peroxidase reaction (E). In many instances the positive reaction of type II cells for ICAM-1 is located at one side of the cell surface. Peroxidase-antiperoxidase adhesive slide assay for the detection of cell surface antigens. (No nuclear counterstain; Original magnification $\times 400$ ).

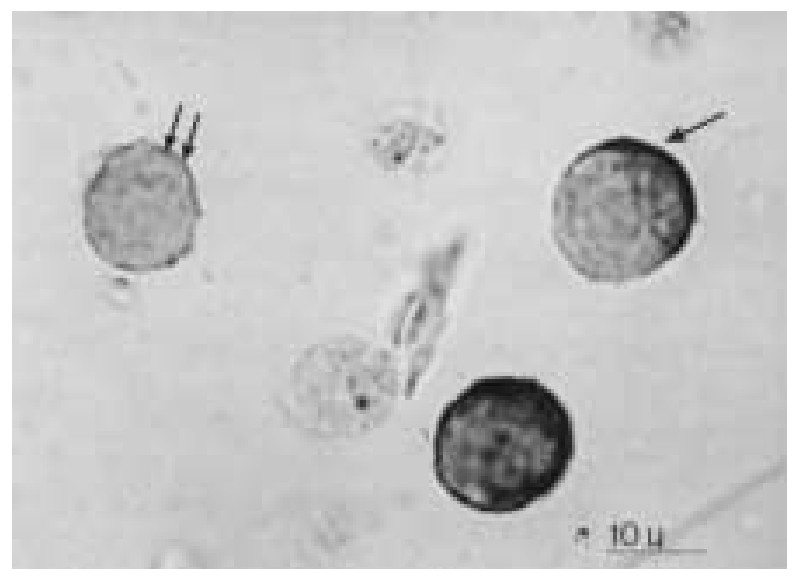

Fig. 3 - Cell surface immunostaining of isolated human type II cells for intercellular adhesion molecule-1 (ICAM-1) (CD54). In many instances the positive reaction is located at one side of the cell surface (arrow). Negative type II cell (two arrows). Peroxidase-antiperoxidase adhesive slide assay for the detection of cell surface antigens. (No nuclear counterstain. Original magnification $\times 1,000$ ).

A weak reaction of only few type II cells (5-10\%) was found for CD49d in 6 out of 10 cases, and for CD51 in 6 out of 10 cases. No significant differences were observed in the reaction pattern of type II cells between nonsmokers and smokers.

\section{Discussion}

In this study, we determined the expression of several adhesion molecules on isolated human type II cells obtained from normal lung tissue of smokers and nonsmokers. A previous immunohistochemical study of the distribution of various integrins in normal human lung tissue was not able to differentiate the various cellular components within the alveolar septae at the light microscopic level using frozen tissue sections [5]. Our approach, using isolated alveolar type II cells, avoided this problem.

Our results show that the majority of human alveolar type II cells express ICAM-1, a minor portion also the alpha-4 (CD49d) subunit of the $\beta 1$-integrins and the alpha-v (CD51) subunit of the vitronectin receptor. This may indicate that type II cells play a direct role in immune and inflammatory responses of the lung, because it is known that ICAM-1 is actively involved in the recruitment of lymphocytes, neutrophils and eosinophils to sites of inflammation [1].

The expression of ICAM-1 may enable type II cells to bind to leucocytes through LFA-1, which is one of the ligands for ICAM-1. This may be an important mechanism in the regulation of the access of leucocytes to the lung parenchyma during pulmonary immune and inflammatory reactions, including idiopathic pulmonary fibrosis, sarcoidosis, and other interstitial lung diseases. ICAM-1 is also constitutively expressed in human bronchial epithelium [12], and its expression increases after allergen challenge in human asthma, in parallel with an increase in neutrophils, eosinophils, T-cells, and mast cells [13]. In addition, ICAM-1 is known to be the major surface receptor for rhinoviruses, which may produce lung diseases [14].

Several cytokines, including interferon- $\gamma($ IFN- $\gamma)$, interleukin-1 (IL-1) and tumour necrosis factor- $\alpha$ (TNF- $\alpha$ ), are able to upregulate the expression of ICAM-1 on leucocytes, endothelial and epithelial cells [1]. Whether this is also valid for human type II cells is, at present, unknown. A recent study showed that, in mice, ICAM1 expression on alveolar type II cells can be markedly induced by hyperoxic exposure [15]. ICAM-1 is involved not only in adhesive properties of activated cells, but also represents an important co-stimulatory signal to $\mathrm{T}$ cell proliferation [16]. In this regard, we recently reported that human leucocyte antigen-DR (HLA-DR) antigens, which are other major molecules supporting T-cell proliferation, are also constitutively expressed on human type II cells [6]. However, the functional activity of alveolar type II cells in relation to antigen T-cell activation is still unknown [17].

Whereas, our study clearly demonstrated ICAM-1 expression on freshly isolated alveolar type II cells obtained from normal human lung parenchyma, CHRISTENSEN et al. [18] reported that in the rat ICAM-1 was not detected on type II cells immediately after isolation, but appeared over $48 \mathrm{~h}$, and was maintained during 7 days in culture; suggesting that ICAM-1 expression might be a differentiation-related characteristic associated with the type I cell phenotype. By using electronmicroscopic immunocytochemistry, KANG et al. [15] showed, in normal mice, that type II cells had considerably lower expression of ICAM-1 than type I cells. Apparently, these divergencies may be explained by species specific differences, with detectable ICAM-1 expression on human alveolar type II cells, as seen in our study, and little or no detectable expression in the mouse [15] and the rat [18]. Since Christensen et al. [18] and our group used similar isolation techniques, including enzymatic digestion and panning, it is unlikely that in vitro activation 
of type II cells during the isolation procedure may have influenced our results.

Obviously, some differences are apparent in the expression of integrins between bronchial epithelial cells and alveolar type II cells. While, previous studies have shown that bronchial epithelial cells express CD49b, the alpha- 2 chain of the collagen receptor, and CD49f, the alpha- 6 chain of the laminin receptor [5, 19], these two $\beta_{1}$-integrin subunits were not expressed by alveolar type II cells in our study. On the other hand, CD49d, the alpha-4 subunit, which can serve both as a fibronectin receptor and as ligand of vascular cell adhesion molecule (VCAM-1), was not expressed by the bronchial epithelium [5] but by a few type II cells in our study. The CD51 (alpha-v) subunit of the vitronectin receptor, however, stained positive with the bronchial epithelium in the previous study [5], and some alveolar type II cells in our study. The biological basis for these differences is uncertain.

In conclusion, this report provides new insights into the phenotype of alveolar type II cells. The observation of the expression of ICAM-1, and also, but to a lesser degree, of some integrin subunits may indicate that these cells participate in local immune and inflammatory responses. The functional correlations and the regulatory mechanisms involved in integrin expression on alveolar type II cells remain areas for further research.

\section{References}

1. Montefort S, Holgate ST, Howarth PH. Leucocyteendothelial adhesion molecules and their role in bronchial asthma and allergic rhinitis. Eur Respir J 1993; 6: 1044-1054.

2. Striz I, Costabel U. The role of integrins in the immune response. Sarcoidosis 1992; 9: 88-94.

3. Hamm H, Bartsch W, Fabel H. The surfactant system of the adult lung: physiology and clinical perspectives. Clin Invest 1992; 56: 185-194.

4. Johansson J, Curstedt T, Robertson B. The proteins of the surfactant system. Eur Respir J 1994; 7: 372-391.

5. Damjanovich L, Albelda SM, Mette SA, Buck CA. Distribution of integrin cell adhesion receptors in normal and malignant lung tissue. Am J Respir Cell Mol Biol 1992; 6: 197-206.

6. Guzman J, Izumi T, Nagai S, Costabel U. Immunocytochemical characterization of isolated human type II cells. Acta Cytol (in press).
7. Dobbs LG, Gonzalez R, Williams MC. An improved method for isolating type II cells in high yield and purity. Am Rev Respir Dis 1986; 134: 141-145.

8. Edelson JD, Shannon JM, Mason RJ. Effects of two extracellular matrices on morphologic and biochemical properties of human type II cells in vitro. Am Rev Respir Dis 1989; 140: 1398-1404.

9. Papadopoulos T, Ionescu L, Dämmrich J, Toomes H, Müller-Hermelink HK. Type I and Type IV collagen promote adherence and spreading of human type II pneumocytes in vitro. Lab Invest 1990; 62: 562-569.

10. Dobbs LG. Isolation and culture of alveolar type II cells. Am J Physiol 1990; 258: L134-L147.

11. Costabel U, Bross KJ, Matthys H. The immunoperoxidase slide assay. A new method for the demonstration of surface antigens on bronchoalveolar lavage cells. Bull Eur Physiopathol Respir 1985; 21: 381387.

12. Montefort S, Roche WR, Howarth PH, et al. Intercellular adhesion molecule-1 (ICAM-1) and endothelial leucocyte adhesion molecule-1 (ELAM-1) expression in the bronchial mucosa of normal and asthmatic subjects. Eur Respir J 1992; 5: 815-823.

13. Montefort S, Carroll M, Gratziou C, Haskard DO, Howarth PH, Holgate ST. Adhesion molecule expression $6 \mathrm{~h}$ after endobronchial allergen challenge in asthmatics. J Allergy Clin Immunol 1993; 91: 822 (Abstract).

14. Staunton DE, Merluzzi VJ, Rothlein R, Barton R, Martin SD, Springer TA. A cell adhesion molecule, ICAM-1, is the major surface receptor for rhinoviruses. Cell 1989; 56: 849-853.

15. Kang BH, Crapo JD, Wegner CD, Letts LG, Chang LY. Intercellular adhesion molecule-1 expression on the alveolar epithelium and its modification by hyperoxia. Am J Respir Cell Mol Biol 1993; 9: 350-355.

16. Van Seventer GA, Shimizu Y, Horgan KJ, Shaw S. The LFA-1 ligand ICAM-1 provides an important co-stimulatory signal for T-cell receptor-mediated activation of resting T-cells. J Immunol 1990; 144: 45794586.

17. Holt PG. Regulation of antigen-presenting cell function(s) in lung and airway tissues. Eur Respir J 1993; 6: $120-129$.

18. Christensen PJ, Kim S, Simon RH, Toews GB, Paine R. Differentiation-related expression of ICAM-1 by rat alveolar epithelial cells. Am J Respir Cell Mol Biol 1993; 8: 9-15.

19. Montefort S, Baker J, Roche WR, Holgate ST. The distribution of adhesive mechanisms in the normal bronchial epithelium. Eur Respir J 1993; 6: 1257-1263. 